Nama : Timothy Davin Soesanto

Kelas : B

NRP : 130218181

\title{
Boosting Indonesia's Tourism Sector to be Competitive
}

Indonesia is a country who relies their income on state budget deficit and current asset deficit. This also has a positive impact on people who involved in tourism activities, in addition to earning income for themselves, people who involved in tourism activities also participate in overcoming economic problems by increasing business fields, reducing current account deficits, and other.

Indonesia has many attractive tourist destinations, such as Borobudur Temple, Mount Bromo, Lake Toba, Raja Ampat, Labuan Bajo, and others. Indonesia's government try to increase number of tourist by accelerate the development of transportation infrastructure, but volcanic eruption, tsunami, and other disaster make it seems so hard. Other problem that also hamper the development of tourism in Indonesia are the lack of promotional activities to attract tourists and the lack of focus on the development of tourist destinations which results in the nonoptimal achievement of the tourism sector.

Actually, Indonesia has enormous tourism potential, but there are several shortcomings that cause Indonesia to become a country that is less comfortable for tourists to visit, one of which is cleanliness which is in the quite bad category. But apart from this, Indonesia is a country that is quite cheap to visit, when compared to Malaysia, Singapore, and even Thailand.

In the tourism sector, the government is targeting to receive 17 billion US dollars, with the number of tourists attending as many as 18 million foreign tourists in 2019. However, the realization that happened was not in accordance with this target, on 1 September 2019, only 9,31 million tourists visited Indonesia. Although the number of visitors is not in line with the target, Indonesia's tourism competitiveness has increased in the ranking of 40 out of 140 countries in 2019 with a value of 4.3. This assessment is based on environmental aspects, travel and tourism conditions, infrastructure, as well as natural and cultural resources. Meanwhile, 
the country with the highest score was Singapore at 17 with a score of 4.8 , followed by Malaysia at 29 with a score of 4.5 , and Thailand at 31 with a score of 4.5 .

At present and in the future the tourism sector is truly relied upon to reduce the current account deficit. The tourism sector was targeted to contribute 17.6 billion US dollars of foreign exchange with the arrival of 18 million foreign tourists in 2019. But the realization until September 1, 2019 only reached 9.31 million foreign tourists, even though Indonesia's tourism competitiveness improved two ranks to 40th out of 140 countries in 2019 with a score of 4.3. The assessment score of 4.3 is based on environmental aspects, travel and tourism conditions, infrastructure, as well as natural and cultural resources. Indonesia's best value in competitiveness is in terms of price, and the lowest value is in environmental sustainability. Singapore is a country in the ASEAN region with the highest ranking, or 17 with a score of 4.8. Malaysia has a score of 4.5 with a ranking of 29 , and Thailand has a score of 4.5 with a ranking of 31 .

In the framework of realizing Indonesia as a leading tourism destination, Indonesia government launched 6 program to make it happen: (1) developing leading destinations; (2) increasing competitiveness; (3) increasing tourism diversity; (4) increasing tourism integration; (5) strengthening as an Asian leading destination; and (6) strengthening as a world leading destination.

Actually Indonesia is a very interesting country to visit, but this beauty is not followed by adequate facilities and cleanliness.

Even though the facilities and cleanliness are inadequate, Indonesian people have high creativity, this is evident in Banyuwangi Regency, such as holding 99 festivals to attract tourists and make tourists stay longer in Banyuwangi with a target of 2.8 days. On average, foreign tourists spend IDR 2.7 million per day per person and domestic tourists spend IDR 1.5 million per day per person in 2018.

The tourism sector does not only offer scenic beauty, especially natural scenery, but also must pay attention to culinary, shopping, and other factors that can make tourists more comfortable. As one example is Bali, where Bali is the main destination for local and foreign tourists. This is because Bali has very beautiful natural scenery and is followed by shopping facilities and culinary tours that are quite suitable for most tourists. 
According to domestic and foreign tourists, price is not a big issue, but tourists want to get a new and enjoyable experience while on vacation. If the price set is quite expensive, but the quality of the vacation and experience offered is good enough, then tourists will not hesitate to pay.

The tourism sector continues to experience rapid development due to changes in people's lifestyles. This is also in line with the findings of Crouch and Ritchie (1999) which state that many factors affect supply and demand in the tourism sector, including factors neglected by many stakeholders, such as clean toilet, high airplane ticket prices. This sector needs attention if Indonesia wants to increase its tourism. If it does not improve, then Indonesia's tourism competitiveness will be inferior to other countries, such as Singapore and China, which routinely innovate and develop creativity.

Currently, tourism and creative industries have become the main income in the national economy to cover the current account deficit and the state budget deficit. The potential of the tourism sector and creative industry is also very supportive of Indonesia's economic growth. To make this happen, cooperation is needed both from the government and from the regions to be able to continue to improve and enhance the tourism sector. The development of Indonesian tourism must be considered from various aspects, not only in infrastructure, but also in the ecosystem in an effort to support tourist destinations, such as aspects of culture, creativity, and hospitality so that people around tourist destinations are not just spectators. Thus, tourism development is expected to provide economic, environmental and local community benefits that are involved in a true sense, and this can improve the Indonesian economy through the tourism sector. 